\title{
ARCHITECTURE IN GLOBAL SOCIALISM \\ EASTERN EUROPE, WEST AFRICA, AND \\ THE MIDDLE EAST IN THE COLD WAR
}

ŁUKASZ STANEK

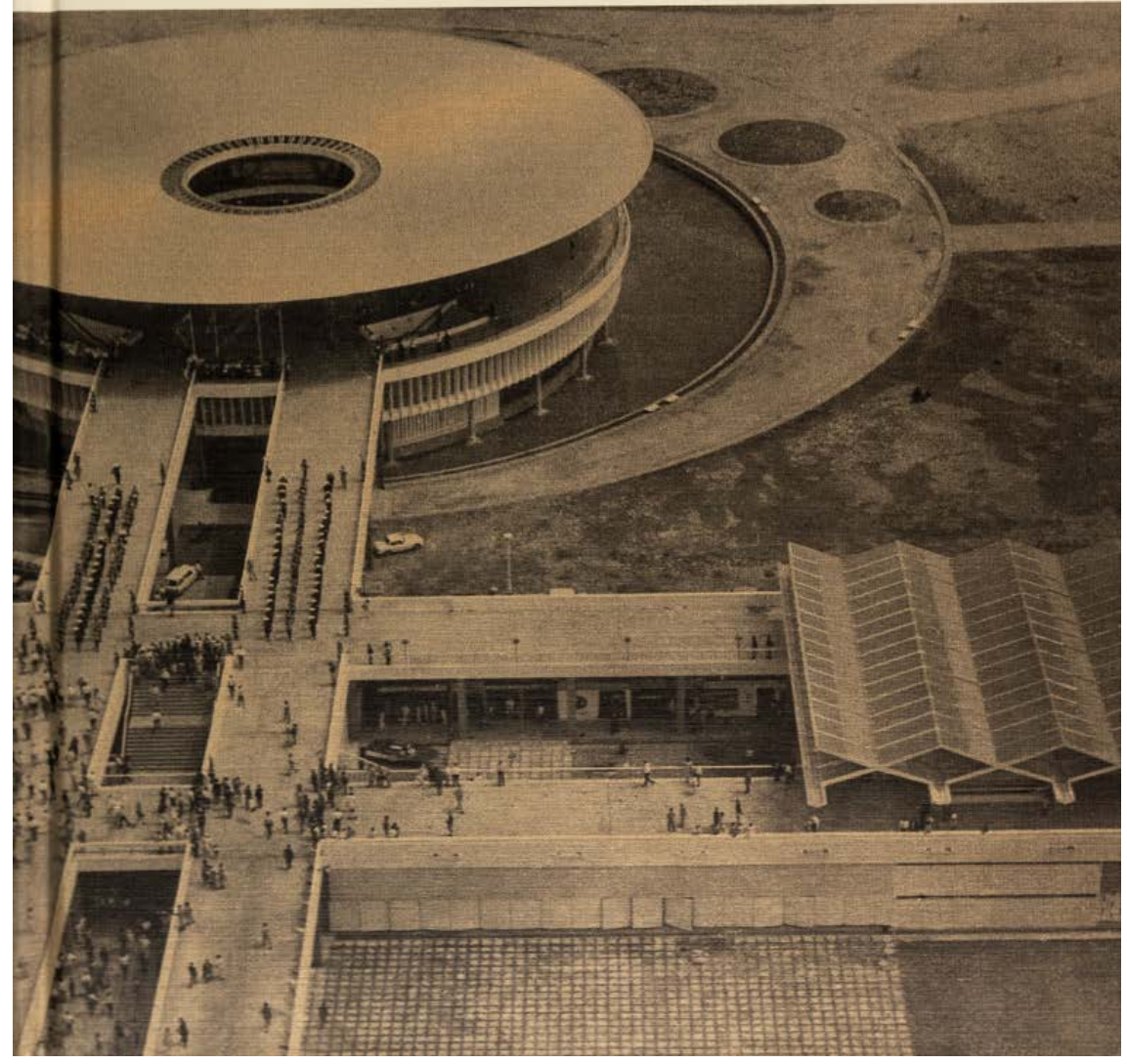




\section{ARHITEKTURA}

NA PERIFERIJI ISTOKA

I ZAPADA

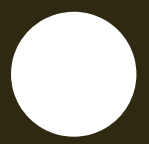

Stanek, Łukasz. Architecture in Global Socialism-Eastern Europe,

West Africa and the Middle East in the Cold War. Princeton-Oxford: Princeton

University Press, 2020. ISBN 9780691168708

DOI: 10.31664/zu.2020.107.11

Poslijeratna diseminacija moderne arhitekture širom dekolonizacijom zahvaćenih kontinenata odvijala se na različite načine. Bez obzira na to je li riječ o projektantskim organizacijama međunarodnoga dometa, poslovnim zajednicama nastalim udruživanjem poduzeća različitih specijalizacija, tehničkoj suradnji, tj. pomoći pojedinih država i međunarodnih institucija, raspisivanju javnih međunarodnih arhitektonskih natječaja ili stručnjacima djelatnima na drugim razinama, uključujući i onu individualno iniciranih migracija, diseminacijski procesi bili su složeni te ih je nemoguće svesti na konačan broj uobičajenih, ustaljenih modela. Premda navedeni oblici stručnoga transfera iz perspektive nastajućeg Trećega svijeta podrazumijevaju import bilo s Istoka bilo sa Zapada, istodobno se u tim zemljama postupno formira i lokalni kadar. Arhitektonski projekti i urbanistički planovi koji nastaju u takvim okolnostima produkt su susreta različitih kultura, arhitektonskih tradicija i građevinskih praksi. Rezultat takve heterogene konjunkture relativno je autonoman, specifičan modernizam, svojstven prostoru Globalnoga Juga.

$\rightarrow$
Stanek, Eukasz. Architecture in Global Socialism - Eastern Europe, West Africa and the Middle East in the Cold War. Princeton-Oxford: Princeton University Press, 2020.

\section{Mojca Smode Cvitanović}

Sveučilište u Zagrebu, Arhitektonski fakultet, Zagreb 
Već u svojim ranijim radovima povjesničar arhitekture Łukasz Stanek ukazao je na pritom evidentno zanemaren doprinos arhitekata socijalističkih zemalja, kako unutar istodobne stručne periodike tako i unutar antologijskih pregleda, locirajući uzroke takvoj segregaciji u prirodi arhitektonskog rada - nasuprot kapitalističkom sustavu unutar kojeg je taj rad smatran slobodnim u centralno upravljanim socijalističkim režimima, nema status autorskog umjetničkog djela, ostvarivanja arhitekturi inherentnoga umjetničkog izraza. U određenom smislu adresirajući i problem pristranosti povijesnog pisanja, knjigom Architecture in Global Socialism -Eastern Europe, West Africa and the Middle East in the Cold War rad „istočnih” arhitekata napokon je ravnopravno historiziran, a kritička povijest arhitekture dobila je nova, do sada „izostavljana” poglavlja. lako fokus knjige nije primarno u domeni povijesti arhitekture, već se, štoviše, uspinje na razinu šire kulturne i društvene povijesti, neizostavno je spomenuti i velika arhitektonska ostvarenja čije kvalitete ovaj korpus arhitektonske produkcije čine povijesno relevantnim.

Knjiga je trebala imati i svoje zagrebačko predstavljanje, koje uslijed aktualne neizvjesne situacije još uvijek očekujemo. Njezino je značenje iz perspektive hrvatske arhitektonske povijesti i teorije druge polovice 20. stoljeća svrstava na police s neizostavnom literaturom. Razlog tome proizlazi iz činjenice da su domaći stručnjaci znatno participirali u razmjeni i diseminaciji ideja, svojim djelovanjem dali prepoznatljiv doprinos, odnosno vrijedna arhitektonska i urbanističko-planerska ostvarenja, realizacije, projekte i planove u zemljama Trećeg svijeta. Konkretno, dosadašnja istraživanja u toj domeni utvrdila su brojku od dvjestotinjak hrvatskih arhitekata koji su u većoj ili manjoj mjeri u promatranom razdoblju ostavili otiske u četrdesetak zemalja Afrike i Azije. lako je tek recentno sintetizirana okosnica te vrste rada, kako u organizacijskom tako i u projektantskom smislu, kvantitativno i kvalitativno nezaobilazan segment hrvatske arhitektonske prakse nedvojbeno je potvrđen, a ovom je knjigom dobio svoju širu kontekstualizaciju, pa i historiografsku valorizaciju. U knjizi istaknuti primjeri-rad grupe arhitekata koja je, predvođena Mirom Marasovićem, djelovala u Gani te rad Urbanističkog instituta Hrvatske na izradi Generalnoga urbanističkog plana Conakryja, glavnoga grada Gvineje-nedvojbeno ukazuju na međunarodnu afirmiranost hrvatske arhitekture. Širenjem rakursa u domenu svih republika socijalističke Jugoslavije broj relevantnih primjera, naravno, znatno raste.

Obrađujući kompleksne slojeve arhitektonsko-urbanističke povijesti Accre, Lagosa, Bagdada, Abu Dhabija i Kuvajta, knjiga daje na uvid golemu količinu bilo nepoznatih bilo zaboravljenih ili u različitim tranzicijama zanemarenih činjenica te postavlja vrijednu idejno-metodološku bazu za izučavanje odnosa između arhitekture i urbanističkog planiranja i društveno-političkih procesa u širem smislu, sagledanih kroz pitanje potencijala arhitekture u imaginaciji i eventualnoj realizaciji nove slike svijeta. Bitno vezana uz antagonizam između socijalističkog Istoka i kapitalističkog Zapada, ideološka se osnova ove knjige ni po čemu ne nameće. Obraćajući se svojem glavnom protagonistu, današnjem Globalnom Jugu, nudi dubinske uvide u pozadinu upravo njegova arhitektonskog naslijeđa. Južne će geografske širine stoga biti ključne za njezinu recepciju, uz nadanje da će ovdje ponuđeno razumijevanje povijesti potaknuti i nove poglede u budućnost.

Recentnu situaciju Globalnoga Juga određuje kapitalistički rast i marginalizacija socijalne politike. Dok sustav razvoja zasnovan na elitama proizvodi siromaštvo, pojava novih razvojnih modela na ovome prostoru ipak se sluti. U domeni arhitekture i urbanizma ta se slutnja očituje kroz iznimno velik interes suvremene arhitektonske teorije i prakse upravo za Globalni Jug. Pri tome se iskoraci često ostvaruju na način da se pomiču uobičajene granice djelokruga discipline, što potkrjepljuje misao da ovaj prostor ponovno postaje platforma socijalno angažiranoga arhitektonskog eksperimenta.

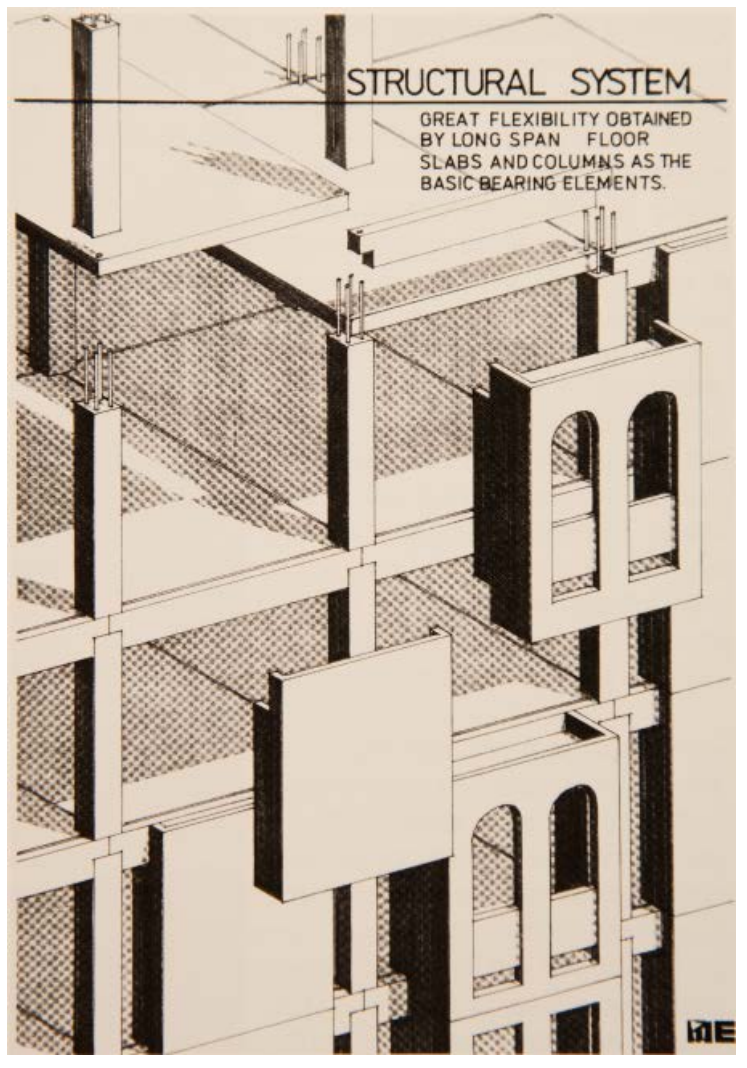

$\cdot$ 

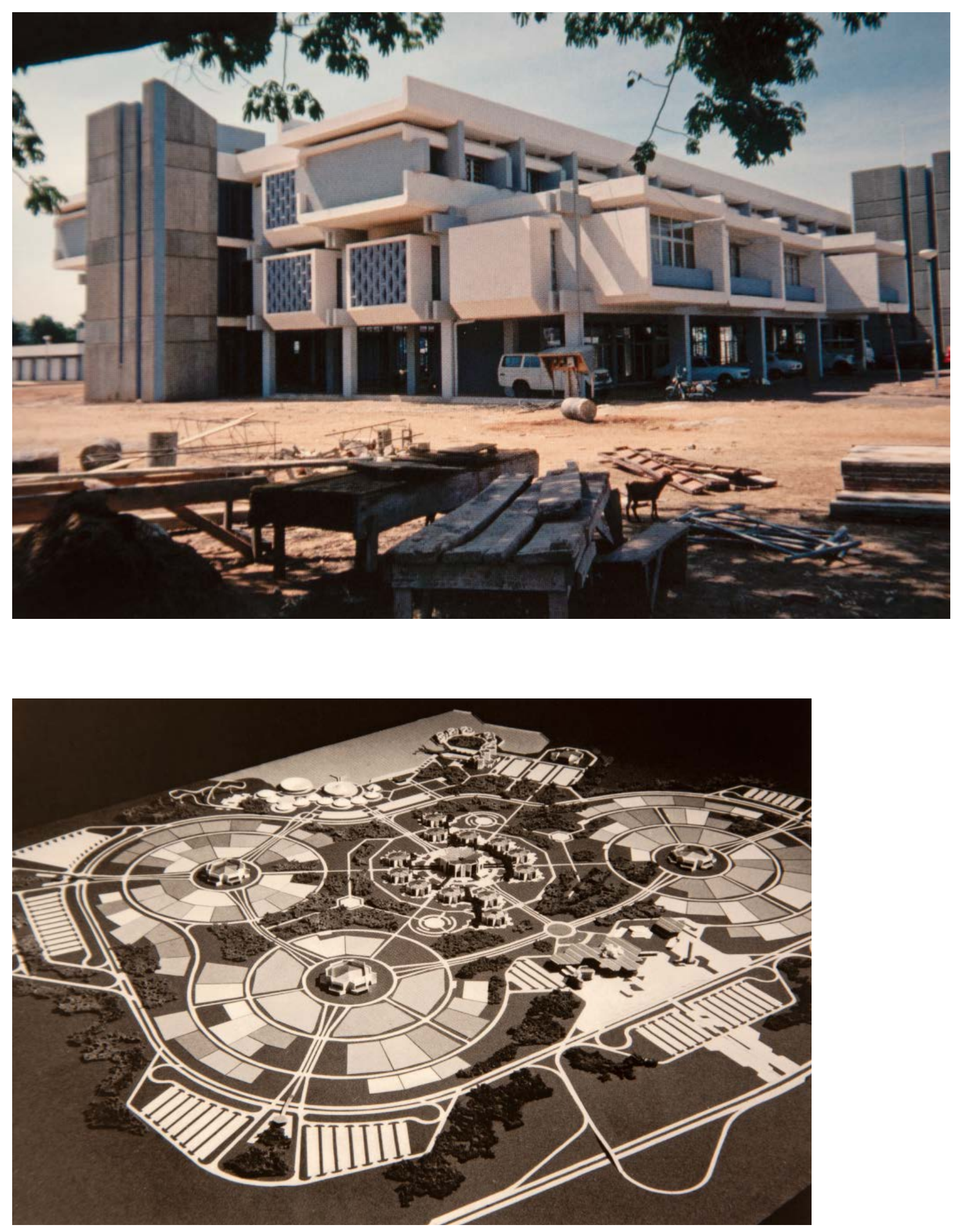